\title{
Foraging by the stoplight parrotfish Sparisoma viride. II. Intake and assimilation of food, protein and energy
}

\author{
J. Henrich Bruggemann, Jaap Begeman, Els M. Bosma, Piet Verburg, Anneke M. Breeman
}

Dept of Marine Biology, University of Groningen, PO Box 14, 9750 AA Haren, The Netherlands

\begin{abstract}
Daily food intake by the herbivorous parrotfish Sparisoma viride, as well as assimilation efficiencies of algal food, protein and energy, were quantified through a combination of laboratory feeding trials and field observations. The intake of algal ash-free dry wt (AFDW) per bite increases linearly with fish wet wt (FWW, g) and algal biomass ( $\mathrm{mg} \mathrm{AFDW} \mathrm{cm}^{-2}$ ), and is further determined by the skeletal density of the limestone substrate. Low-density substrates yield higher amounts of AFDW per bite than do high-density substrates. The percentage of the total food intake that is derived from endolithic and crustose coralline algae increases with the size of the fish, and can be $>70 \%$ depending on the biomass of epilithic algae. The daily pattern of foraging activity is positively correlated with diurnal changes in food quality, while seasonal daylength variations result in $13 \%$ variation in total daily bites taken. Daily number of bites of $S$. viride in the field decreases with fish size, and is further dependent on life phase and foraging depth. In experiments, fish attained an assimilation efficiency of ca $20 \%$ from a natural diet of low algal biomass and high-density dead coral substrates that predominates in the shallow reef. Assimilation efficiency was ca $70 \%$ from a diet of high algal biomass and lowdensity substrates that predominates on the deeper reef parts. In spite of lower daily foraging effort, territorial fish, living in deeper parts of the reef, ingest and assimilate higher amounts of AFDW, protein and energy per day than non-territorial fish foraging on the shallow reef. The difference is caused by increased availability of high-yield food and substrate types inside territories compared to the situation on the shallow reef. Daily assimilated energy $\left(\mathrm{kJ} \mathrm{d}^{-1}\right)$ is $0.85 \times \mathrm{FWW} \mathrm{W}^{0.773}$ for fish foraging in the shallow reef zone, and $1.22 \times \mathrm{FWW}^{0854}$ for $S$. viride foraging inside territories on the deeper reef.
\end{abstract}

KEY WORDS: Herbivorous fish - Scaridae - Dãily food intake - Assimilation efficiency - Protein . Energy $\cdot$ Social organization

\section{INTRODUCTION}

Herbivory on some coral reefs is probably more intense than in any other habitat, either terrestrial or marine (Hatcher \& Larkum 1983, Carpenter 1986, Lewis 1986, Choat 1991). On reefs subject to minimal human disturbance, fish, as the main consumers of the primary production, are often estimated to consume between 50 and $100 \%$ of total algal production (Carpenter 1986). Parrotfish (family Scaridae) have been widely recognized as a major component of the herbivorous fish community (Williams 1982, Russ 1984a, b, Choat \& Bellwood 1985), and can be expected to play an important role in the transfer of food materials and energy from primary producers to the remaining members of the food chain.
Being large and mobile, parrotfish are intense feeders which can profoundly affect the diversity and biomass of reef-inhabiting algae (Brock 1979). In terms of feeding biology, and in analysis of the fish community structure, it has been convenient to view scarids as a relatively uniform group of grazing herbivores that scrape filamentous algae from the reef matrix (Choat 1991). Bellwood \& Choat (1990), however, have recently questioned this assumption, and concluded that parrotfish are a diverse group with marked ecological and behavioural differences within the family, occupying a wide range of habitats with different substrata. As a consequence, the impact of these herbivores on the algal communities will vary with species composition and reef habitat.

Scarids are notable in their ability to sustain large population sizes and high growth rates (Russ 1984a, b, 
Russ \& St. John 1988, J. van Rooij, J. H. Bruggemann \& J. J. Videler unpubl.) on food sources which have small standing crop (Hatcher 1983, Russ 1987, Steneck 1988) and which are low in protein (Bowen 1987). However, little is known quantitatively about food intake and assimilation efficiency in scarids (Horn 1989, Choat 1991). The few experimental studies of foraging in herbivorous reef fish tended to concentrate on small territorial species, such as members of the family Pomacentridae (Polunin 1988, Klumpp \& Polunin 1989). The paucity of quantitative studies of food intake in larger herbivorous reef fish is probably associated with their mobility and with the difficulty of making direct abservations in the field. Moreover, due to their large size and the nature of their food (algae associated with the reef matrix), manipulative studies in the laboratory are difficult and laborious.

The daily intake, assimilation and allocation of energy by a common scarid were investigated in a larger project, aiming to evaluate the role of parrotfish in the trophodynamics of coral reefs. The stoplight parrotfish Sparisoma viride (Bonnaterre) was chosen as study animal. This species is a large generalist herbivore that is common on Caribbean reefs. Food selection by $S$. viride has been described by Bruggemann et al. (1994, this issue), while a description of fish growth is provided by van Rooij et al. (unpubl.). Here, daily intake and assimilation of food, protein and energy by $S$. viride are described. More specifically the objectives of this study were to: (1) quantify the daily intake and assimilation of food and nutrients by different life phases and size classes of $S$. viride; and (2) quantify the effect of foraging depth on the acquisition and assimilation of algal food.

This study represents the first published quantitative description of food intake by a larger herbivorous reef fish.

\section{MATERIAL AND METHODS}

Study site and study animals. Experimental work was carried out at Karpata Ecological Centre, situated on the leeward coast of Bonaire, Netherlands Antilles, while field observations were made on the fringing reef in front of the field station. For a detailed description of the reef at the study site see Bruggemann et al. (1994). The parrotfish Sparisoma viride is an important herbivore on Caribbean reefs, both in terms of population density and algal biomass consumed. It forages only by day, grazing on epilithic, crustose and endolithic algae growing on and in dead coral substrates. S. viride employs an excavating grazing mode that leaves deep scars in the limestone (Gygi 1975).
The species is a protogynous hermaphrodite and 3 life phases are distinguished: juveniles (JU: $<15 \mathrm{~cm}$ fork length, FL, measured from the tip of the upper jaw to the end of the middle caudal rays): initial phase (IP: 15 to $35 \mathrm{~cm} \mathrm{FL}$ ), mostly female; and terminal phase males (TP: 18 to $43 \mathrm{~cm} \mathrm{FL}$ ). Its social organization confines individuals to limited parts of the reef. On the shallow reef ( 0 to $3.5 \mathrm{~m}$ depth) loosely associated groups of IP and TP fish share a common home range. Territories, shared by 3 to 7 haremic females, are maintained and fiercely defended against conspecifics by single TP males on the deeper parts of the reef $(4$ to $25 \mathrm{~m}$ depth). JU fish are found in highest densities on the drop-off reef zone (6 to $12 \mathrm{~m}$ depth).

Fish used in the laboratory for feeding trials were captured near the study site either at night using hand nets and an anaesthetic (quinaldine, 'Aquavet Seaquin'), or by day using a seine net $(84 \mathrm{~m}$ long $\times 10 \mathrm{~m}$ deep, $5 \mathrm{~cm}$ stretched mesh). Fish were transferred to the laboratory where they were kept in tanks with a continuous supply of seawater that was pumped from the reef. Tanks with a capacity of 115 l were used for juveniles, while $1000 \mathrm{l}$ or $3500 \mathrm{l}$ tanks were used for adults. Shade nets were used to protect the tanks from direct incident light, minimizing temperature increase in the daytime. Fish wet weight (FWW) and fork length were determined for fish with empty guts, anaesthetized in a $10 \mathrm{ppm}$ solution of quinaldine to facilitate handling. FWW was determined to the nearest $0.1 \mathrm{~g}$ on an electronic scale (Sartorius PT1200), or to the nearest $\mathrm{g}$ using a triple-beam balance (Ohaus), and fork length was determined to the nearest $\mathrm{mm}$ with the aid of a measuring board. Between experiments, fish were fed ad libitum with algae growing on coral rubble that was collected from the nearby reef. Before the onset of each experiment, all coral rubble was removed, and all debris was siphoned out of the tanks. JU and IP fish were kept in pairs of approximately equal weight, while TP males were held individually.

Food intake experiments. The amount of algal food ingested per bite was calculated from the decrease in algal biomass after a known number of bites on blocks of dead coral substrate covered with a natural vegetation. Parts of dead coral bearing a homogeneous algal vegetation, representing characteristic food and substrate types, were collected from the main feeding areas of Sparisoma viride (see Bruggemann et al. 1994). Substrates originating from Acropora cervicornis and A. palmata colonies were collected from the shallow reef zone $(<3 \mathrm{~m}$ depth) where nonterritorial fish feed. Montastrea annularis substrates were collected in the deeper reef ( $>4 \mathrm{~m}$ depth) from the feeding areas of territorial fish. The substrate blocks were trimmed, and subsequently cut into halves using a diamond gem-saw (Raytech Industries) To 
verify uniformity of algal growth on either half, the mean percentage cover of filamentous, crustose and endolithic algae was determined from 20 randomly chosen quadrats of $6.25 \mathrm{~mm}^{2}$, using a dissecting microscope at $60 \times$ magnification. The 2 halves were considered to have a uniform algal cover if the means of either half did not differ by more than $10 \%$. A random sample of 20 quadrats was sufficient to obtain a reproducible estimate of the mean cover by different vegetation components. Designation of experimental and control halves (blocks) was decided by the flip of a coin. To allow later calculation of the no. of bites $\mathrm{cm}^{-2}$, the total surface area of experimental blocks was determined by modelling heavy-duty aluminum foil of known weight tightly over the algae-covered surface of the block, and then weighing the foil.

The experimental blocks were mounted on heavy concrete bricks with iron wire and placed in the tanks with fish, and the number of bites taken on each block was counted. A block was removed when a decrease in algal cover could be detected with the naked eye. During the experiment, the control blocks were kept under identical conditions as experimental blocks, but without fish being present. Experimental and control blocks were cut in 3 subsamples. From each subsample, the surface area was determined as above, and algal biomass ( $\mathrm{mg}$ AFDW $\mathrm{cm}^{-2}$ ) was determined using the method described by Bruggemann et al. (1994). Food intake per bite (mg algal AFDW) is calculated as:

mean biomass $_{\text {control blocks }}$ - mean biomass experimental blocks no. of bites $\mathrm{cm}^{-2}$

Each experiment consisted of a series of experimental blocks offered to a fish (or pair of fish) of known weight. The coral origin of the substrate, as well as algal biomass, height and cover of filamentous algal fronds, cover of crustose corallines, and thickness of the endolithic layer on experimental and control blocks were noted. We tested whether the relation between fish weight and food intake per bite differed between substrate types, regardless of differences in algal vegetation on these substrates, using ANCOVA (Norusis 1990 ) in which fish weight was taken as covariate. If not different, substrate types were pooled, and the effect of algal vegetation parameters on food intake per bite was analyzed for each substrate type/group (ANCOVA and linear regression). In some experiments, differences in the ratio of surface area to perimeter and/or the no. of bites $\mathrm{cm}^{-2}$ between experimental blocks significantly affected the food intake per bite. This experimental bias was analyzed with multiple regression techniques (Norusis 1990), and corrected for using the corresponding regression equations.
Grazing fish ingest varying amounts of the endolithic algal layer, depending on their size, but they do not excavate this layer completely, as witnessed by the blue-green colour of grazing scars. Epi-and endolithic algal fractions differ in chemical composition (Bruggemann et al. 1994). In order to enable estimation of protein and energy intake per bite, the relative proportion of epilithic and 'substrate-bound' algae (endolithic algae and crustose corallines) was assessed. The percentage of the total food intake per bite that was derived from substrate-bound fractions was calculated from the total food intake per bite minus the intake derived from epilithic algae. Ingestion of epilithic algae was calculated from the surface area of grazing scars (see Bruggemann et al. 1994) and the epilithic biomass. Biomass of epilithic algae on Acropora spp. substrates was determined by Bruggemann et al. (1994: Table 5, sparse turfs on endolithic algae $=1.3 \pm 0.1 \mathrm{mg}$ AFDW $\mathrm{cm}^{-2}$ ). Experimental Montastrea annularis substrates supported higher biomass of epilithic algae, as indicated by increased canopy height and higher percentage cover of epilithic algae (see Table 1). For these substrates, epilithic biomass was estimated by subtracting biomass of endolithic algae as determined by Bruggemann et al. (1994: Table 5, endolithic algae =

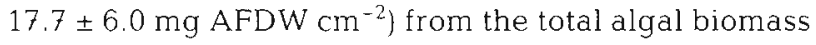
determined for the experimental substrates. Bite scars left by experimental fish were smaller than those left by free-living fish on the reef (see below), and the relationship between fish fork length and surface area removed per bite was corrected for accordingly.

Food assimilation experiments. Assimilation efficiencies of algal food were determined by direct methods, which involved quantitative measurement of food consumed and faeces produced, and indirect methods, in which the nutrient content of the food was compared with that of the faeces using ash as an assumed non-absorbed marker. The latter method was applicable only to juvenile fish feeding exclusively on epilithic algae that have a relatively constant ash fraction. Larger fish scrape off and ingest large but unknown quantities of carbonates, varying with fish size, food type and skeletal density of substrates (Bruggemann et al. 1994), thus preventing estimates of ash fractions in the food.

Fish were kept over a mesh-wire grate, and fed ad libitum on a diet consisting of coral rubble with associated algae, which was collected from either of the 2 main feeding areas for non-territorial and territorial Sparisoma viride respectively (see above). In the assimilation trials we used coral rubble from the same locality, originating from the same coral species and supporting similar algal biomass, as was used in the food intake experiments. Before the onset of each experiment the fish were allowed to get accustomed to 
their diet for at least $1 \mathrm{~d}$. Feeding rates ( $F R$, no. of bites $\mathrm{h}^{-1}$ ) were determined 8 times $\mathrm{d}^{-1}$ at regular intervals from $07: 30$ to $18: 30 \mathrm{~h}$. The daily number of bites taken by experimental fish was estimated from extrapolation of the feeding rates to the total daily feeding period from dawn to dusk (see 'Foraging effort'). Daily intake of algal food (AFDW $W_{\text {in }}, \mathrm{mg}$ ) was calculated as the product of the daily total number of bites and the experimentally determined food intake per bite. In juveniles that feed only on the epilithic algal fronds, the food intake per bite is not dependent on substrate type. Their food intake per bite was calculated using the regression coefficient of food intake per bite from Montastrea annularis, as this substrate type supported highest percentage cover and biomass of epilithic algae (Table 1). At the end of the day all faeces were siphoned from under the grate, collected in buckets and left overnight to allow particulate matter to settle on the bottom. The supernatant was decanted, and the faeces filtered over $5 \mu \mathrm{m}$ filters (Schleicher \& Schuell, no. AE98) under vacuum. The faeces was dried to constant weight at $60^{\circ} \mathrm{C}$, after which the organic fraction was determined (see below). Biochemical composition of faeces was corrected for the loss of organic matter and nutrients between egestion and analysis of faeces. Fresh faeces was collected by massaging the faeces out of the caecum of the fish, and homogenized by stirring. Part of this faeces was dried immediately and served as control, while the rest was divided over a number of Petri dishes, and placed in the tanks under conditions identical to those during experiments. After variable test periods from 3 to $24 \mathrm{~h}$, duplicate faecal samples were siphoned from randomly selected Petri dishes, and the organic fraction and protein contents of control and treated samples were determined following the procedures described below. Faecal nutrient loss was independent of time (least-squares regression of $\%$ nutrient loss to time; organic matter: $r=-0.302$, $\mathrm{p}=0.510, \mathrm{n}=7$; protein: $\mathrm{r}=+0.378, \mathrm{p}=0.403, \mathrm{n}=7$ ), indicating that loss of nutrients is caused by collecting and filtering of faeces prior to analysis rather than slow dissolution in the tanks. Loss of organic matter averaged $14 \pm 2 \%(n=7)$, while on average $16 \pm 4 \%(n=7)$ of faecal protein disappeared. It was assumed that the energy contents decreased to the same extent as that of protein (16\% correction). The biochemical composition of daytime faeces was corrected for accordingly. The first defecation of the day, which could easily be distinguished by the mucus film wrapped around it, consists of undigested food remains from the previous day. This 'morning turd' could in most cases immediately be removed whole, and no correction was applied to this portion of the daily defecations. Daily excretion of organic matter (AFDW $W_{e x}, \mathrm{mg}$ ) was calculated as the product of faeces dry wt and the corrected organic fraction. The proportion of the total food that was absorbed is the 'total assimilation efficiency' $(\%)$, which was calculated as:

$$
\left[\left(\mathrm{AFDW}_{\mathrm{in}}-\mathrm{AFDW}_{\mathrm{ex}}\right) / \mathrm{AFDW}_{\mathrm{in}}\right] \times 100 \text {, }
$$

and the proportion of a given nutrient assimilated is the 'nutrient assimilation efficiency' (\%), which was calculated as:

$\frac{\% \text { nutrient } \times \mathrm{AFDW}_{\mathrm{nn}}-\% \text { nutrient } \times \mathrm{AFDW}_{\mathrm{ex}}}{\% \text { nutrient } \times \mathrm{AFDW}_{\mathrm{in}}} \times 100$.

The (indirect) ash-marker method was used to determine assimilation efficiencies in small JU fish $(\leq 10 \mathrm{~cm}$ FL). They were offered a diet consisting of large algal turfs. To determine the ash fraction of the food, filamentous algae were carefully collected to avoid contamination with carbonate particles or small invertebrates, then dried and ashed (see below). Absorption efficiencies of total algal AFDW and of nutrients were calculated employing the equations of Montgomery \& Gerking (1980, p. 146).

Biochemical analysis. The organic fraction (\% AFDW) of samples, dried to constant weight at $60^{\circ} \mathrm{C}$, was determined by weighing and reweighing duplicate subsamples after ashing at $500^{\circ} \mathrm{C}$ for at least $6 \mathrm{~h}$. Algal biomass ( $\mathrm{mg}$ algal AFDW $\mathrm{cm}^{-2}$ ), as well as protein ( $\mathrm{mg} \mathrm{g}^{-1}$ AFDW) and energy ( $\mathrm{kJ} \mathrm{g}^{-1}$ AFDW) contents of food and faeces, were determined following the procedures described by Bruggemann et al. (1994).

To investigate the variation in nutritional quality of algal food over the day, 3 replicate samples of sparse algal turfs were collected at 06:00, 12:00, 18:00 and 00:00 h on 15 January 1991. Since the biomass of sparse algal turfs is very low, each sample was composed of 4 separately collected subsamples. Ash content was determined from replicate subsamples $(n=3)$ as described above. Protein and energy contents were determined from $\mathrm{C}$ and $\mathrm{N}$ weight fractions using the stoichiometric method (Gnaiger \& Bitterlich 1984), following procedures described by Bruggemann et al. (1994). Soluble carbohydrates were extracted by treating replicate $(\mathrm{n}=2)$ subsamples of $200 \mathrm{mg}$ with hot $\left(100^{\circ} \mathrm{C}\right) 2 \mathrm{M} \mathrm{HCl}$ for $2.5 \mathrm{~h}$ (Hashimoto et al. 1987). Total soluble carbohydrates were determined by the Anthron method (Morse 1949) using glucose as a standard.

Comparison of bites taken by captive and freeliving fish. To verify the validity of the experimentally determined food intake per bite of Sparisoma viride, the sizes of grazing scars from captive fish were compared to those from fish foraging on the reef. The bite size, i.e. the surface area removed and the volume of substrate excavated, was determined from the scars left by grazing fish as described by Bruggemann et al. (1994). The mean size of bites recorded from fish kept 
in captivity $(\mathrm{CB})$, and that from free-living fish on the reef $(\mathrm{FB})$, were compared pairwise, controlling for fish fork length, substrate type and observer. Differences were tested with the Student's $t$-test (Norusis 1990). Correction factors for surface areas and volumes were calculated as FB/CB for all pairs. The effects of fish fork length and substrate type on the correction factors were tested separately for substrate area and volume of bites with ANOVA (Norusis 1990).

Foraging effort of Sparisoma viride in the field. Field observations of foraging fish were performed using SCUBA, with notes recorded on PVC sheets. Before recording started, the fish were allowed to become accustomed to the presence of the observer for approximately 5 min, during which time the fork length was estimated to the nearest $\mathrm{cm}$. The total number of bites taken during 30 min periods was recorded at regular intervals from dawn to dusk, and the time of day, foraging depth and life phase were noted. Temperature was recorded at $6 \mathrm{~m}$ depth at the end of each observation period.

To determine the total daily foraging period, the feeding activity of Sparisoma viride was recorded at dawn and dusk relative to the times of sunrise and sunset. Light intensity (photosynthetically active radiation, PAR) was measured simultaneously using a LiCor 192SA quantum sensor which was positioned horizontally on the seabed at $5 \mathrm{~m}$ depth, and a LiCor 1000 datalogger. Times of sunrise and sunset were defined as the times of solar elevation of $-0.833^{\circ}$ (when the upper rim of the sun is level with the horizon), and calculated for the latitude of the study area using the equations described by Dring (1984). Length of the daylight period (DLP) was defined as the time (in h) from sunrise to sunset.

The effects of time of day, fork length, life phase, foraging depth, temperature and season on FR were investigated in 2 series of observations. The first was performed in February, May and August 1989, 3 distinct periods of the year, aiming to encompass a wide range in seasonal temperature and daylength fluctuations. Fish belonging to 4 size classes (i.e. JU fish $10 \pm 1 \mathrm{~cm} \mathrm{FL}$, IP fish of $20 \pm 1$ and of $30 \pm 1 \mathrm{~cm} \mathrm{FL}$ and
TP males) were selected in the shallow reef zone and on the deeper reef, and their FRs were recorded (119 30-min protocols). In the second observation series, from May to September 1991, the daily foraging effort of 15 individually recognizable (tagged) TP males of known weight was recorded twice with time intervals ranging from 1 to 4 mo (216 30-min protocols). Feeding activity varies over the day, and the variable 'time of day' can be a confounding factor in the evaluation of the effect of the other variables on FR. When the dataset was restricted to observations made between 09:00 and 17:00 h, no interaction between time of day and the other variables was detected. Therefore, observations made between 09:00 and 17:00 h were used to investigate factors affecting FR (ANCOVA; Norusis 1990).

The total daily number of bites (TDB) was determined from observation series of individual fish, or of well-defined size classes, of which the feeding activity throughout the day was monitored ('daycover'). Complete daycovers were made 28 times at various times of the year for 15 different TP males (territorial and non-territorial individuals), and for fish of $10 \pm 1 \mathrm{~cm}$ FL (JU), $30 \pm 1 \mathrm{~cm} \mathrm{FL} \mathrm{(IP),} \mathrm{and} 40 \pm 2 \mathrm{~cm} \mathrm{FL} \mathrm{(TP)}$ foraging on the deeper reef. Using these daycover observations, the relationship between DLP, TDB and FR between 09:00 and 17:00 $\mathrm{h}$ was determined empirically.

\section{RESULTS}

\section{Food intake per bite}

In Table 1 the characteristics of the experimental substrate types and their associated algal vegetation are summarized. All experimental blocks contained either large or sparse algal turfs; the undergrowth consisted of endolithic algae with a varying proportion of the surface covered with crustose corallines. Substrates bearing endolithic algae and/or crustose corallines, but devoid of epilithic algae, were not used during the experiments.

Table 1. Dead coral substrate types and characteristics of associated algal vegetation used in food intake experiments. Mean \pm SE for each substrate group is shown

\begin{tabular}{|c|c|c|c|c|c|c|c|}
\hline \multirow[t]{2}{*}{ Substrate type } & \multirow{2}{*}{$\begin{array}{l}\text { Substrate } \\
\text { density } \\
\left(\mathrm{g} \mathrm{cm}^{-3}\right)\end{array}$} & \multirow{2}{*}{$\begin{array}{c}\text { Total algal } \\
\text { biomass } \\
\left(\mathrm{mg} \mathrm{AFDW} \mathrm{cm} \mathrm{cm}^{-2}\right)\end{array}$} & \multicolumn{2}{|c|}{ Epilithic algal turfs } & \multirow{2}{*}{$\begin{array}{l}\text { Crustose } \\
\text { corallines } \\
\text { (\% cover) }\end{array}$} & \multirow{2}{*}{$\begin{array}{c}\text { Endolithic } \\
\text { algal layer } \\
\text { (mm) }\end{array}$} & \multirow{2}{*}{$\begin{array}{l}\text { No. of ex- } \\
\text { perimental } \\
\text { blocks }\end{array}$} \\
\hline & & & (mm height) & ( $\%$ cover) & & & \\
\hline Acropora cervicornis & $2.1 \pm 0.3$ & $14.3 \pm 2.8$ & $2.7 \pm 1.4$ & $49.0 \pm 16.4$ & $35.6 \pm 29.1$ & $1.2 \pm 0.5$ & 17 \\
\hline A. palmata & $1.8 \pm 0.2$ & $19.4 \pm 4.5$ & $3.3 \pm 1.2$ & $51.6 \pm 16.5$ & $13.4 \pm 22.1$ & $1.1 \pm 0.4$ & 61 \\
\hline Montastrea annularis & $1.3 \pm 0.2$ & $21.5 \pm 5.5$ & $4.5 \pm 1.2$ & $65.4 \pm 18.7$ & $9.1 \pm 18.7$ & $1.4 \pm 0.9$ & 68 \\
\hline
\end{tabular}


Algal biomass differed significantly between substrate types (ANOVA, $F_{(2,144)}=16.038, \mathrm{p}<0.001$ ). Subsequent comparison of means (Scheffé; Norusis 1990) showed that Acropora cervicornis had lowest biomass, while algal biomass on Montastrea annularis substrate was highest. Algal biomass on Acropora spp. substrates combined was lower than on $M$. annularis substrate (Scheffé, $F_{11.145)}=15.810, \mathrm{p}<0.001$ ). Separately and combined, both Acropora spp. substrate types had significantly lower turf height (Scheffé, $F_{(1.140)}=24.467$, $p<0.001$ ), lower cover of epilithic algal turfs (Scheffé, $\left.F_{(1,145)}=25.186, p<0.001\right)$, and higher cover of crustose corallines (Scheffé, $F_{(1,145)}=6.341, \mathrm{p}=0.013$ ) than $M$. annularis substrates. The thickness of the endolithic algal layer was the only vegetation parameter that did not differ significantly among substrate types (Scheffé, $\left.F_{(1.134)}=0.931, p=0.336\right)$.

One-way ANCOVA, in which fish weight was taken as covariate, showed no significant difference in food intake per bite between the substrate types Acropora cervicornis and $A$. palmata (ANCOVA, $F_{(1,77)}=0.181$, $\mathrm{p}=0.672$ ). Food intake per bite differed significantly between $A$. cervicornis and Montastrea annularis substrates $\left(\mathrm{ANCOVA}, F_{(1.85)}=5.648, \mathrm{p}=0.020\right)$, and between $A$. palmata and $M$. annularis substrates $\left(\right.$ ANCOVA, $\left.F_{(1.128)}=29.76, p<0.001\right)$. In the subsequent analysis the results of experiments with the high-density substrates from the shallow reef $(A$. cervicornis and A. palmata) were pooled and treated separately from those obtained with the low-density substrate from the deeper reef areas (M. annularis).

Food intake per bite increases linearly with fish weight on all substrate types. In Fig. 1 the least-squares regression of the food intake per bite against fish weight is given for each substrate group. When grazing on dead Montastrea annularis substrates, the fish attain a higher food intake per bite than when grazing on dead Acropora spp. substrates. For both substrate groups, the deviation from the mean food intake per bite within experiments can be explained by differences in algal biomass on the experimental blocks (ANOVA, $F_{16,136)}=$ $4.225, p=0.001$ ) (Fig. 2). The other vegetation parameters, i.e. percentage cover of epilithic algae and of crustose corallines, and the thickness of the endolithic algal layer did not significantly affect the food intake per bite (ANOVA, epilithic turfs: $F_{(5,141)}=0.783, \mathrm{p}=0.564$; crustose corallines: $F_{\mid 5.141\}}=1.559, \mathrm{p}=0.176_{i}$ endolithic algae: $\left.F_{(6,129)}=0.582, \mathrm{p}=0.744\right)$. A 1 -way ANCOVA, in which algal biomass was taken as a covariate, showed that the effect of algal biomass on food intake per bite was not significantly different for the 2 substrate groups (ANCOVA, $F_{(1,145)}=1.526, p=0.219$ ). In Fig. 2 the leastsquares regression describing the deviation from the mean food intake per bite (within experiments) as a function of algal biomass is given.

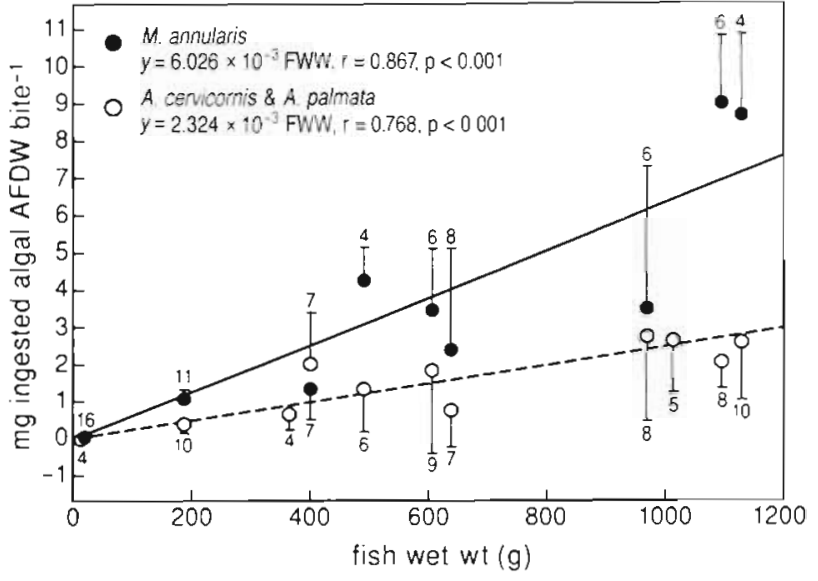

Fig. 1. Sparisoma viride. Food intake per bite by stoplight parrotfish as a function of fish wet wt (FWW) and substrate type. Experimental substrates with associated algae were collected from the main feeding areas of the fish: the shallow reef zone (Acropora cervicornis and A. palmata substrates) and the deeper reef areas (Montastrea annularis substrates). The least-squares regression lines are forced through the origin (intercept was not significantly different from zero. $p>0.05$ ). Error bar indicates SE of mean food intake per bite for each fish (pair) and substrate type. Only upper or lower error bar is shown for figure clarity. Numbers indicate no. of experimental blocks

The percentage of the total food intake per bite that is derived from crustose and endolithic algae increases with the size of the fish (Fig. 3). Juvenile Sparisoma viride, up to $10 \mathrm{~cm} \mathrm{FL}$, eat only epilithic algal turfs. The proportion of substrate-bound algal fractions in the diet increases rapidly between 10 and $20 \mathrm{~cm} \mathrm{FL}$, and

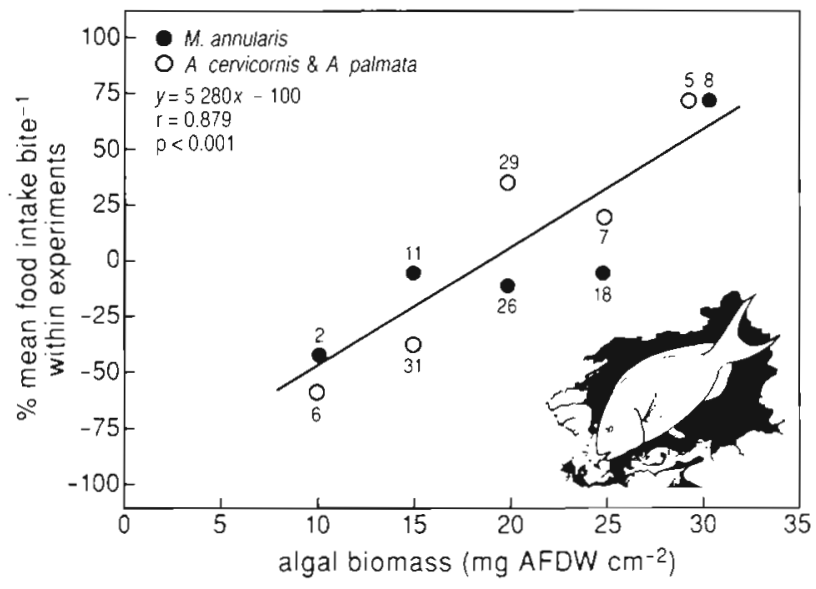

Fig. 2. Sparisoma viride. Effect of algal biomass on food intake per bite. The residuals of the mean food intake per bite within experiments are plotted against algal biomass. Mean algal biomass on the different substrate types is given in Table 1 Calculated least-squares regression line through all experimental data is shown. Numbers indicate no. of experimental blocks 


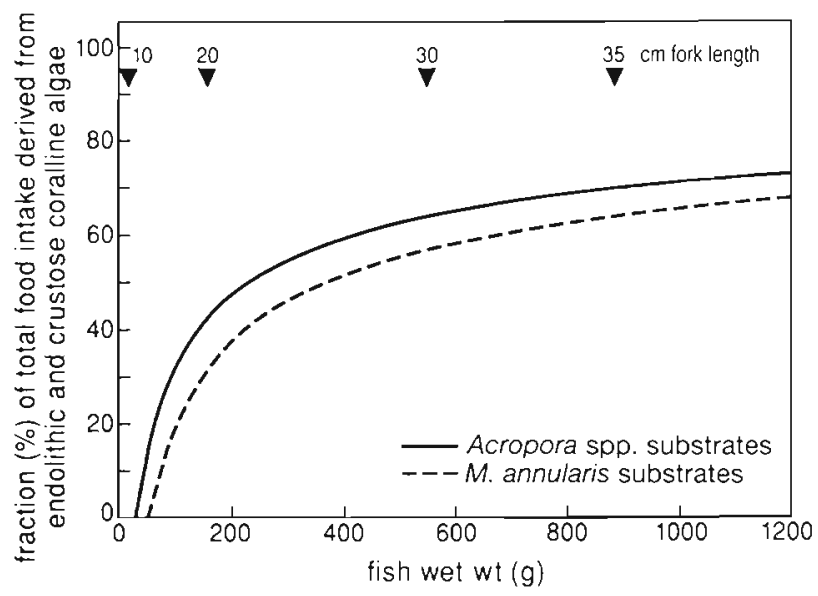

Fig. 3. Sparisoma viride. Estimated percentage of the total food intake per bite derived from endolithic and crustose coralline algae as a function of fish size. Percentage intake from substrate-bound algal fractions is calculated as $100 \%$ food intake per bite - \% food intake from epilithic algae. Intake per bite from epilithic algae is calculated from the surface area of bites in captivity and estimated biomass of epilithic algae on Acropora spp. and Montastrea annularis substrates respectively more slowly from $20 \mathrm{~cm}$ FL onward. When grazing on Acropora spp. substrates, which have a low epilithic biomass, a larger proportion of the food intake per bite is derived from endolithic and crustose coralline algae than when grazing on Montastrea annularis substrates, that support a higher epilithic biomass.

\section{Food assimilation experiments}

The results of food assimilation experiments are presented in Table 2. Calculated with the direct method, the total assimilation efficiency for adult fish that graze on high-density and low-biomass Acropora spp. substrate types averages $20.2 \pm 17.8 \%(n=44)$, which is considerably lower than the average assimilation efficiency of $70.5 \pm 13.2(n=12)$ obtained from a lowdensity and high-biomass diet on Montastrea annularis substrates. The assimilation efficiency attained by juvenile fish feeding on epilithic algal turfs averaged $67.1 \pm 11.1 \%(\mathrm{n}=22)$. The assimilation efficiency for juveniles obtained from the ash-marker method is much lower: $23.2 \pm 8.6 \%(n=3)$.

Table 2. Sparisoma viride. Total assimilation efficiency for different diets, calculated using direct and indirect methods. Food intake per bite from each substrate type was calculated using the least-squares regression equation of food intake per bite and fish weight (Fig. 1). Ac+Ap: Acropora cervicornis and A. palmata; Ma: Montastrea annularis. Means \pm SD are calculated over all experimental days

\begin{tabular}{|c|c|c|c|c|c|c|c|}
\hline \multirow{3}{*}{$\begin{array}{l}\text { Life } \\
\text { phase } \\
\text { JU }\end{array}$} & \multirow{3}{*}{$\begin{array}{c}\text { Mean fish } \\
\text { weight } \\
\text { (g) }\end{array}$} & \multirow{3}{*}{$\begin{array}{c}\begin{array}{c}\text { Substrate } \\
\text { type }\end{array} \\
-\end{array}$} & \multirow{3}{*}{$\begin{array}{l}\begin{array}{c}\text { Duration } \\
\text { (d) }\end{array} \\
14\end{array}$} & \multirow{3}{*}{$\begin{array}{c}\begin{array}{c}\text { Mean intake/ } \\
\text { bite } \\
(\mathrm{mg} \mathrm{AFDW}\end{array} \\
0.0404\end{array}$} & \multirow{3}{*}{$\begin{array}{c}\text { Mean egestion/ } \\
\text { bite } \\
\text { (mg AFDW } \\
0.0110\end{array}$} & \multicolumn{2}{|c|}{ Total assimilation efficiency $(\%)$} \\
\hline & & & & & & $\begin{array}{l}\text { Direct } \\
\text { method }\end{array}$ & $\begin{array}{l}\text { Indirect } \\
\text { method }^{\alpha}\end{array}$ \\
\hline & & & & & & $72.8 \pm 8.8$ & $23.9 \pm 8.5$ \\
\hline JU & 15 & - & 4 & 0.0898 & 0.0391 & $56.5 \pm 7.9$ & $22.7 \pm 8.6$ \\
\hline \multirow[t]{2}{*}{ JU } & 18 & - & 4 & 0.1091 & 0.0460 & $57.9 \pm 6.1$ & $23.0 \pm 8.6$ \\
\hline & & & & & & mean: $67.1 \pm 11.1$ & mean: $23.2 \pm 8.6$ \\
\hline IP & 183 & $A C+A p$ & 5 & 0.4253 & 0.3389 & $20.3 \pm 12.6$ & - \\
\hline IP & 362 & $\mathrm{Ac}+\mathrm{Ap}$ & 8 & 0.8401 & 0.6170 & $26.6 \pm 4.0$ & - \\
\hline IP & 397 & $A C+A p$ & 3 & 0.9233 & 0.8786 & $4.8 \pm 8.9$ & - \\
\hline IP & 561 & $\mathrm{Ac}+\mathrm{Ap}$ & 5 & 1.2964 & 1.0387 & $19.9 \pm 4.1$ & - \\
\hline IP & 571 & $\mathrm{Ac}+\mathrm{Ap}$ & 5 & 1.3277 & 1.1705 & $11.8 \pm 6.5$ & - \\
\hline IP & 640 & $A c+A p$ & 4 & 1.4874 & 1.0280 & $30.9 \pm 23.0$ & - \\
\hline TP & 958 & $A c+A p$ & 1 & 2.2264 & 1.7543 & $21.1-$ & - \\
\hline TP & 973 & $\mathrm{Ac}+\mathrm{Ap}$ & 5 & 2.2613 & 2.0516 & $9.3 \pm 4.9$ & - \\
\hline $\mathrm{TP}$ & 1099 & $A c+A p$ & 5 & 2.5541 & 2.0950 & $18.0 \pm 5.1$ & - \\
\hline \multirow[t]{2}{*}{ TP } & 1130 & $\mathrm{AC}+\mathrm{Ap}$ & 3 & 2.6245 & 1.5827 & $39.7 \pm 40.3$ & - \\
\hline & & & & & & mean: $20.2 \pm 17.8$ & - \\
\hline IP & 183 & Ma & 2 & 1.1028 & 0.2600 & $76.4 \pm 12.9$ & - \\
\hline IP & 397 & Ma & 3 & 2.3941 & 1.0227 & $57.1 \pm 16.1$ & - \\
\hline IP & 640 & Ma & 2 & 3.8566 & 1.1499 & $70.2 \pm 3.9$ & - \\
\hline TP & 973 & Ma & 2 & 5.8633 & 1.3838 & $76.4 \pm 0.5$ & - \\
\hline \multirow[t]{2}{*}{ TP } & 1099 & Ma & 2 & 6.6226 & 1.5674 & $76.3 \pm 0.5$ & - \\
\hline & & & & & & mean: $70.5 \pm 13.2$ & - \\
\hline
\end{tabular}


Intake of protein and energy was calculated from AFDW $_{\text {in }}$ (Table 2), the relative amounts of epilithic and substrate-bound algal fractions in the different diets of experimental fish (Fig. 3), and the biochemical composition of these algal fractions (Table 5 in Bruggemann et al. 1994). Faecal protein content of adult fish was determined for every experimental day; for juveniles the faecal protein content was determined for 2 successive days during each experiment. Faecal caloric content was determined in 22 samples: 15 samples from a wide size-range of fish from different assimilation experiments, and 7 samples collected as fresh 'morning turds' from free-living fish on the reef. Caloric content of experimental and field faeces was not significantly different ( $t=-1.36$, df $=20, p=0.215$ ), and averaged $17.3 \pm 0.3 \mathrm{~kJ} \mathrm{~g}^{-1}$ AFDW. With 1 exception, the average assimilation efficiencies for protein and energy are higher than the average total assimilation efficiencies (Table 3). Only juveniles showed lower assimilation efficiency for protein than for total AFDW, as determined with the direct method. This was due to a slightly higher protein content in their faeces compared to the protein content of their algal food. Protein and energy assimilation efficiencies from the diet on Montastrea annularis substrates were higher than from those on the Acropora spp. substrate diet

Table 3. Sparisoma viride. Assimilation efficiencies of protein and energy calculated using direct methods. Substrate types: Ac: Acropora cervicornis Ap: A. palmata; Ma: Monastrea annularis. Means \pm SD are calculated over all experimental days

\begin{tabular}{|c|c|c|c|c|c|}
\hline \multirow{3}{*}{$\begin{array}{l}\text { Life } \\
\text { phase } \\
\text { JU }\end{array}$} & \multirow{3}{*}{$\begin{array}{c}\text { Mean fish } \\
\text { weight (g) } \\
5\end{array}$} & \multirow{3}{*}{$\begin{array}{c}\text { Substrate } \\
\text { type } \\
-\end{array}$} & \multirow{2}{*}{$\begin{array}{l}\text { Duration } \\
\text { (d) }\end{array}$} & \multicolumn{2}{|c|}{ Assimilation efficiency $(\%)$} \\
\hline & & & & Protein & Energy \\
\hline & & & 14 & $69.4 \pm 9.9$ & $78.0 \pm 7.1$ \\
\hline JU & 15 & - & 4 & $47.8 \pm 9.5$ & $64.5 \pm 6.5$ \\
\hline \multirow[t]{2}{*}{ JU } & 18 & - & 4 & $51.5 \pm 7.0$ & $65.6 \pm 5.1$ \\
\hline & & & me & $: 62.2 \pm 13.4$ & mean: $73.3 \pm 9.1$ \\
\hline IP & 183 & $A c+A p$ & 5 & $69.5 \pm 8.0$ & $33.1 \pm 11.7$ \\
\hline IP & 362 & $\mathrm{Ac}+\mathrm{Ap}$ & 8 & $67.5 \pm 2.5$ & $42.0 \pm 3.9$ \\
\hline IP & 397 & $A c+A p$ & 3 & $70.3 \pm 2.8$ & $26.0 \pm 6.9$ \\
\hline IP & 561 & $A c+A p$ & 5 & $62.3 \pm 3.0$ & $38.3 \pm 3.4$ \\
\hline IP & 571 & $A C+A p$ & 5 & $56.5 \pm 2.8$ & $31.8 \pm 5.3$ \\
\hline IP & 640 & $A c+A p$ & 4 & $65.6 \pm 18.0$ & $46.6 \pm 17.0$ \\
\hline TP & 958 & $A C+A p$ & 1 & $56.2-$ & $40.9-$ \\
\hline TP & 973 & $A C+A p$ & 5 & $51.9 \pm 16.7$ & $29.7 \pm 3.4$ \\
\hline TP & 1099 & $A C+A p$ & 5 & $67.3 \pm 1.9$ & $37.5 \pm 3.6$ \\
\hline \multirow[t]{2}{*}{ TP } & 1130 & $A C+A p$ & 3 & $76.2 \pm 22.2$ & $62.7 \pm 31.0$ \\
\hline & & & mec & $64.7 \pm 12.7$ & mean: $38.8 \pm 15.1$ \\
\hline IP & 183 & Ma & 3 & $88.4 \pm 6.4$ & $81.9 \pm 10.0$ \\
\hline IP & 397 & Ma & 3 & $80.1 \pm 8.0$ & $68.0 \pm 12.0$ \\
\hline IP & 640 & $\mathrm{Ma}$ & 2 & $86.1 \pm 7.8$ & $76.6 \pm 3.4$ \\
\hline TP & 973 & $\mathrm{Ma}$ & 2 & $88.7 \pm 1.0$ & $82.1 \pm 0.4$ \\
\hline \multirow[t]{2}{*}{ TP } & 1099 & Ma & 2 & $88.8 \pm 1.1$ & $82.3 \pm 0.5$ \\
\hline & & & me & $86.1 \pm 7.0$ & mean: $77.6 \pm 9.9$ \\
\hline
\end{tabular}

\section{Size of grazing scars in captivity and in the field}

The surface area and volume of bites was determined from 323 bite scars taken by fish of 27,30 and $36 \mathrm{~cm}$ FL that were kept in the laboratory. Only bite scars from bites taken on the substrate types that were used in the food intake and assimilation experiments were included. On the same substrate types, the size of bites from fish having similar fork length $( \pm 2 \mathrm{~cm}$ ) was determined from 143 bite scars observed on the reef. The size of bites taken in the field (FB) is usually bigger than of bites taken in captivity (CB), but the difference is not always significant (Table 4). The conversion factor $(F B / C B)$ is not significantly dependent on fish fork length (ANOVA; surface area: $F_{(2,3)}=0.928$, $\mathrm{p}=0.519 ;$ volume: $\left.F_{(2,3)}=0.228, \mathrm{p}=0.814\right)$ or substrate type (ANOVA; surface area: $F_{(1,4)}=2.809, p=0.192$; volume: $F_{(1,4)}=0.318, p=0.612$ ), and therefore an average conversion factor was calculated for surface area $(1.32 \pm 0.33)$ and volume $(1.61 \pm 0.40)$.

\section{Foraging effort of Sparisoma viride}

Total daily foraging period. At first light, the fish leave their nighttime resting places and go to their daytime feeding sites. The onset and cessation of feeding activity is determined by light intensity rather than the times of sunrise and sunset. For all size classes averaged, the feeding activity starts $53 \pm 10$ min after sunrise and stops $16 \pm 8$ min after sunset, with corresponding light intensities of $24 \pm$ 14 and $19 \pm 13 \mu \mathrm{E} \mathrm{m} \mathrm{m}^{-2} \mathrm{~s}^{-1}$. The mean light intensities at the times of the first and last bite of the day are not significantly different $(t=0.980$, df $=32$, $p=0.333$ ). In the morning, the minimum light intensity for feeding comes late relative to the time of sunrise. This is caused by the location of the study site, being at the base of limestone cliffs that cast a shadow in the morning. Averaged for all size classes of Sparisoma viride, the daily foraging period at Karpata equals the daylight period (DLP) $-0.62 \mathrm{~h}$, and ranges from $10.80 \mathrm{~h}$ in December to $12.23 \mathrm{~h}$ in June.

Initial phase fish of $30 \mathrm{~cm}$ FL started feeding at significantly higher light intensities than the other size classes (ANOVA Scheffé, $F_{(3.14)}=5.368, \mathrm{p}<$ 0.05). The light intensity at the time of the last bite of the day was significantly higher for JU fish than for IP 
Table 4. Sparisoma viride. Comparison of mean bite size of experimental and field fish. Substrate types: Ac: Acropora cervicornis; Ap: A. palmata; Ma: Montastrea annularis. ns: not significant

\begin{tabular}{|c|c|c|c|c|c|c|}
\hline $\begin{array}{l}\text { Fork length } \\
\qquad(\mathrm{cm})\end{array}$ & $\begin{array}{l}\text { Substrate } \\
\text { type }\end{array}$ & \multicolumn{2}{|c|}{ Mean size \pm SE of $n$ bites of fish in: } & & $\mathrm{p}$ & $\begin{array}{l}\text { Correction } \\
\text { factor }\end{array}$ \\
\hline \multicolumn{7}{|c|}{ Surface area removed $\left(\mathrm{mm}^{2}\right)$} \\
\hline 27 & $\mathrm{Ac}+\mathrm{Ap}$ & $36.1 \pm 1.5 \quad(102)$ & $34.2 \pm 3.8$ & $(20)$ & ns & 0.95 \\
\hline 30 & $A c+A p$ & $62.4 \pm 9.1$ & $95.6 \pm 12.6$ & (26) & 0.034 & 1.53 \\
\hline 30 & $\mathrm{Ma}$ & $45.4 \pm 8.4$ & $67.6 \pm 9.7$ & (10) & ns & 1.49 \\
\hline 36 & $\mathrm{Ac}+\mathrm{Ap}$ & $71.3 \pm 2.1 \quad(168)$ & $70.7 \pm 5.7$ & (61) & ns & 0.99 \\
\hline \multirow[t]{2}{*}{36} & $\mathrm{Ma}$ & $62.6 \pm 10.5$ & $103.6 \pm 12.7$ & (23) & ns & 1.66 \\
\hline & & & & & & mean: 1.32 \\
\hline \multicolumn{7}{|c|}{ Substrate volume removed $\left(\mathrm{mm}^{3}\right)$} \\
\hline 27 & $\mathrm{Ac}+\mathrm{Ap}$ & $13.0 \pm 0.9 \quad(102)$ & $17.6 \pm 3.7$ & $(18)$ & ns & 1.35 \\
\hline 30 & $A C+A p$ & $43.8 \pm 7.8$ & $81.5 \pm 14.0$ & (26) & 0.013 & 1.86 \\
\hline 30 & $\mathrm{Ma}$ & $43.4 \pm 6.6$ & $55.9 \pm 9.9$ & (10) & ns & 1.29 \\
\hline 36 & $A C+A p$ & $38.5 \pm 2.3 \quad(168)$ & $51.9 \pm 6.6$ & (56) & ns & 1.34 \\
\hline \multirow[t]{2}{*}{36} & $\mathrm{Ma}$ & $37.6 \pm 9.9$ & $82.8 \pm 17.0$ & (23) & 0.031 & 2.20 \\
\hline & & & & & & mean: 1.61 \\
\hline
\end{tabular}

fish of $30 \mathrm{~cm}$ FL and TP males, but not significantly different from IP fish of $20 \mathrm{~cm}$ FL (ANOVA Scheffé, $\left.F_{(3,14)}=5.023, \mathrm{p}<0.05\right)$. In consequence, IP fish of $30 \mathrm{~cm}$ FL start their feeding day on average $15 \mathrm{~min}$ later than other size classes, while small fish stop feeding approximately $10 \mathrm{~min}$ earlier than larger individuals.

Factors affecting feeding rate. In Fig. $4 \mathrm{~A}$ all FR observations are plotted against the time of day. FR increases from early morning until noon, followed by a

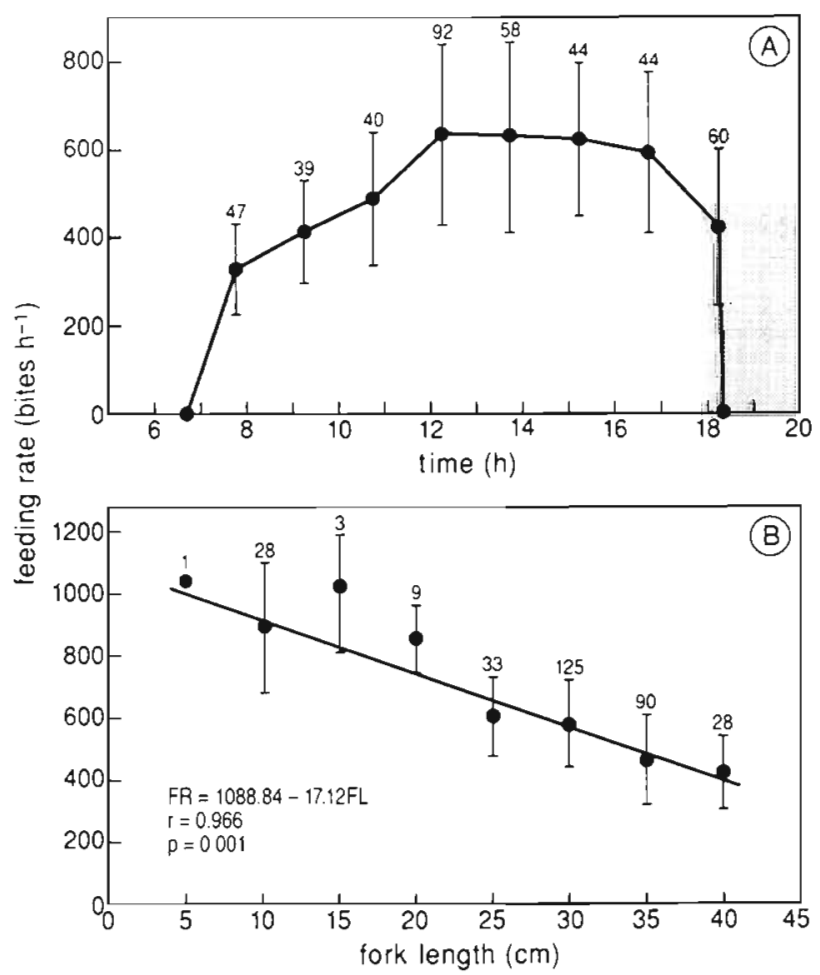

period with highest FR from noon to approximately $1 \mathrm{~h}$ before dusk. This pattern of feeding activity is typical for all observed Sparisoma viride, regardless of size, life phase or foraging depth, and does not change qualitatively over the year. Over $70 \%$ of the total daily bites are taken after midday.

The feeding rate depends on fish size, life phase and foraging depth. It is inversely linearly related to fork length: smaller fish have higher FR than larger fish. The least-squares regression function of FR to FL is

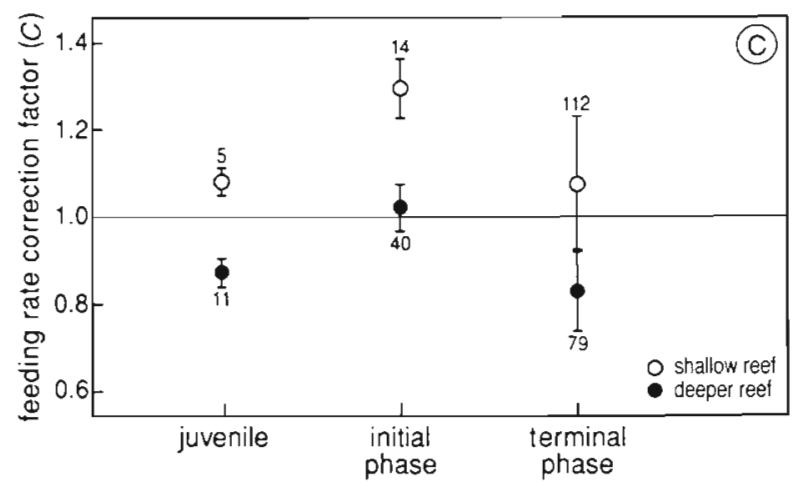

Fig. 4. Sparisoma viride. (A) Daily pattern of feeding activity. Feeding rates \pm SD of all size classes are plotted against time of day. Value above error bar indicates no. of observations; shaded area indicates time when sun is below the horizon. (B) Effect of fish fork length (FL) on feeding rate (FR). Leastsquares regression is fitted through the weighted means $\pm \mathrm{SD}$ of FR for each $5 \mathrm{~cm}$ size class. Dataset is restricted to feeding rate observations made between 09:00 and 17:00 h. Numbers indicate no. of observations for each size class. (C) Effect of life phase and foraging depth on feeding rate. Ratio of group means $\pm \mathrm{SD}$ to the regression predictions of $\mathrm{FR}$ to $\mathrm{FL}$ are plotted as feeding rate correction factor. Numbers indicate no. of observations in each group 
given in Fig. 4B. Analysis of residuals of the linear regression of FR to FL showed significant effects of life phase and foraging depth (2-way ANCOVA, $F_{(2,258)}=$ $41.114, \mathrm{p}=0.000$ ). IP Sparisoma viride achieve higher feeding rates than both JU and TP fish, and fish foraging on the shallow reef show higher feeding rates than $S$. viride foraging on the deeper reef areas (Fig. 4C). The feeding rate between 09:00 and 17:00 h can be estimated using the formula:

$$
F R=C(1088.84-17.12 \mathrm{FL}),
$$

in which $C$ represents a correction factor, depending on life phase and foraging depth (Fig. 4C). Seawater temperatures ranged from 26.2 to $29.6^{\circ} \mathrm{C}$ in the observation period; however, no significant effect of temperature on FR was detected. No effect of season (month of observation) on FR was detected either.

Daily number of bites. From 28 daycover observations, the relation between FR (from 09:00 to 17:00 h), the daylight period, and the total daily bites was established empirically. TDB can be estimated using the equation ( $\mathrm{n}=28, \mathrm{r}=0.983, \mathrm{p}<0.001$ )

$$
\mathrm{TDB}=284.8+0.84[\mathrm{FR}(\mathrm{DLP}-0.62)] \text {. }
$$

\section{Variations in food quality with time of day}

The biochemical composition of epilithic sparse algal turfs at different times of day is given in Table 5. Ash contents and soluble carbohydrates showed significant changes over a $24 \mathrm{~h}$ period. Ash contents decreased from 06:00 to $18: 00 \mathrm{~h}$, and increased during the night. At 18:00 h the ash content was significantly lower compared to the other sampling times $(\mathrm{p}=0.018)$. The amount of soluble carbohydrates increased during the day, followed by a decrease during the night. Soluble carbohydrate contents were significantly higher at
18:00 h compared to other sampling times $(p=0.014)$. Protein and energy contents did not vary significantly with time of day.

\section{DISCUSSION AND CONCLUSIONS}

\section{Food intake per bite: effects of food and substrate types}

The intake of algal food that is attained from bites taken on dead Montastrea annularis substrates is over 2.5 times higher than the food intake attained from bites on Acropora spp. substrates. This difference can partly be attributed to differences in vegetation on the experimental substrates. Algal biomass is higher on $M$. annularis substrates than on Acropora spp. substrates (21.7 and $18.3 \mathrm{mg}$ AFDW $\mathrm{cm}^{-2}$ respectively). However, if the effect of algal biomass on the attained food intake per bite is corrected for (using the equation in Fig. 2), the food intake per bite from M. annularis is still 2.2 times higher than that from Acropora spp. substrates. Not only the biomass, but also the composition of the algal vegetation differed between experimental substrates. Acropora spp. substrates had a lower cover of epilithic algae, and a higher cover of crustose corallines than $M$. annularis (Table 1). Crustose corallines yield smaller amounts of algal food per bite, mainly resulting from smaller grazing scars (Bruggemann et al. 1994). Different specific densities of the substrates further contribute to the observed differences in food intake. Bruggemann et al. (1994) demonstrated that the specific density of a substrate affects the size of bite scars left by grazing Sparisoma viride: low-density substrates $(M$. annularis) showed bigger grazing scars than high-density substrates (Acropora spp.). During the food intake experiments, we frequently observed that fish were able to denude the surface of $M$. annularis blocks of its algae at a much greater speed than for Acropora spp. substrates. In the process, more limestone was also excavated from the former substrate types.

\begin{tabular}{|lcccccc|}
\hline $\begin{array}{l}\text { Biochemical } \\
\text { composition }\end{array}$ & $06: 00 \mathrm{~h}$ & $12: 00 \mathrm{~h}$ & $18: 00 \mathrm{~h}$ & $00: 00 \mathrm{~h}$ & $F$ & $\mathrm{p}$ \\
\hline Ash (\% drý wt) & $83.1 \mathrm{a}$ & $81.2 \mathrm{a}$ & $76.1 \mathrm{~b}$ & $78.5 \mathrm{a}$ & 6.143 & 0.018 \\
& $(0.9)$ & $(1.3)$ & $(1.5)$ & $(1.2)$ & & \\
Soluble carbohydrates & $54.8 \mathrm{a}$ & $63.5 \mathrm{a}$ & $89.0 \mathrm{~b}$ & $70.4 \mathrm{a}$ & 6.725 & 0.014 \\
(mg g-1 AFDW) & $(3.4)$ & $(10.2)$ & $(0.6)$ & $(3.1)$ & & \\
Protein (\% AFDW) & $21.0 \mathrm{a}$ & $18.8 \mathrm{a}$ & $17.2 \mathrm{a}$ & $18.3 \mathrm{a}$ & 1.555 & 0.274 \\
& $(1.3)$ & $(1.9)$ & $(0.6)$ & $(1.0)$ & & \\
Energy & $17.8 \mathrm{a}$ & $17.7 \mathrm{a}$ & $17.6 \mathrm{a}$ & $17.6 \mathrm{a}$ & 0.742 & 0.557 \\
(kJ g ${ }^{-1}$ AFDW) & $(0.1)$ & $(0.4)$ & $(0.1)$ & $(0.1)$ & & \\
\hline
\end{tabular}

\section{Effect of fish size on composition of ingested algal food}

When attaining a larger size, fish not only increase their net food intake per bite, but are also faced with a change in composition of the ingested food. Juvenile Sparisoma viride feed almost exclusively on the fronds of epilithic algal 
turfs, but as fish grow, an increasing fraction of the ingested food consists of endolithic algae and crustose corallines (Fig. 3). The surface area of bite scars increases linearly with fork length squared (Bruggemann et al. 1994), as does the amount of epilithic algae ingested. The total food intake increases linearly with fish weight, which is a function of fork length cubed. As $S$. viride gains size, the increase in yield from epilithic algae does not match the increase in total AFDW ingested, implying an increasing fraction of the food ingested being harvested from endolithic algal fractions.

When fish are grazing on low-biomass Acropora spp. substrates, a larger proportion of the total food intake per bite is derived from endolithic algal fractions than when they graze on high-biomass Montastrea annularis substrates. This difference is caused by differences in epilithic algal biomass, biomass being higher on $M$. annularis substrates. A smaller proportion of the total food intake per bite being derived from substratebound algal fractions does not imply that the volume of bites on $M$. annularis substrates is smaller. In fact, when the biomass of substrate-bound algae is assumed to be equal for both substrate groups (a reasonable assumption as the thickness of the endolithic layer was not different for the different substrate types, and the biomass of endolithic algae and crustose corallines is not significantly different; see Bruggemann et al. 1994), the higher food intake per bite that Sparisoma viride attains from grazing on $M$. annularis is harvested in bigger bites, excavating larger quantities of endolithic and crustose coralline algae.

\section{Factors affecting feeding rate}

The feeding rate is defined as the number of bites per hour. Size-related differences in feeding rate may result from differences in bite rate (no. of bites $\mathrm{s}^{-1}$ ), or from a varying proportion of the time spent on other activities, such as swimming and social interactions with conspecifics. Although there is a negative relationship between bite rate and fish size (slope of linear regression of bite rate to fish fork length: $-0.045 ; r=0.533 ; p<0.001$; Bruggemann unpubl. data), this alone cannot account for the reduced feeding rates of larger fish. This implies that smaller fish spend less time on other activities than larger individuals. In a behavioural study of Sparisoma viride, Hanley (1984) noted that small individuals were more sedentary and swam less than larger individuals. As an explanation Hanley proposed that small $S$. viride can utilize different food resources, being smaller in size, than large individuals. Small food resources may be uneconomical for large individuals to exploit, as suggested by the longer swimming times and longer feeding bouts of the latter. Our observations of feeding rates in relation to fish size seem to confirm the hypothesis of different size-related food resources being exploited by $S$. viride.

The effect of life phase on feeding rate can be explained by differences in exploited food resources and by differences in social activity between individuals. JU fish spend less time swimming between food patches than other life phases, but spend more time hovering and looking, presumably for animal prey, before taking a swift bite. The relative feeding rate of JU fish (Fig. 4C) is lower than that of IP fish. TP Sparisoma viride also have lower relative feeding rates than IP fish. TP males spend more time on social interactions, related to the defence or potential conquest of territories, than do other life phases (van Rooij pers. comm.). Gladstone (1988) reported reduced feeding rates in territorial males of the sharpnose puffer Canthigaster valentini and hypothesized this to be a consequence of the duties associated with defending a territory and maintaining social contact with haremic females. IP fish do not partake much in territorial defence; relative to the other life phases, they spend the largest proportion of the day on feeding, presumably to meet the high metabolic demands of daily egg production.

Lower feeding rates on the deeper reef may be related to the spatial distribution of food. The increased structural heterogeneity on the deeper reef (see Table 1 in Bruggemann et al. 1994) causes the food distribution to be more patchy than on the shallow reef. As a consequence, fish on the deeper reef are obliged to swim more between feeding bouts (van Rooij unpubl. data), resulting in lower feeding rates.

\section{Feeding rate and diurnal variation in food quality}

Sparisoma viride varies its feeding rate with time of day. The change in feeding rate is correlated with biochemical changes in epilithic algal turfs. Sparse and large turfs constitute important food items for $S$. viride. Both food types are dominated by red algae (Bruggemann et al. 1994). Algal turfs show a decreasing ash content in the course of the day, which means that the potentially digestible organic (AFDW) fraction increases. The soluble carbohydrate content also increases with time of day. The acid-soluble fraction of the total carbohydrates in red algae mainly consists of monosaccharides, such as glucose, fructose and galactose, and of alpha-linked storage polysaccharides, such as Floridean starch (Craigie 1974). As amylase activity is high in the guts of herbivorous fish (Fish 1960, Gohar \& Latif 1961), higher fractions of 
soluble carbohydrates imply greater digestibility of algal food during the afternoon. S. viride seems to exploit these changes in food quality by exerting higher feeding rates during the second half of the day, resulting in $>70 \%$ of total daily bites being taken after midday. Polunin \& Klumpp (1989) also found that the daily pattern of feeding activity of herbivorous fish (pomacentrids and acanthurids) is correlated with diurnal changes in food quality. In a study of 2 different populations of a herbivorous blenny species, Zoufal \& Taborsky (1991) concluded that the diurnal foraging periodicity matches the changes in energy content of the algal food. The origins of the diurnal changes in energy content were, however, not explained.

\section{Assimilation efficiency of total organics, protein and energy}

Determining the assimilation efficiency in juvenile Sparisoma viride using the algal ash fraction as an indigestible marker (Montgomery \& Gerking 1980, Horn \& Neighbors 1984, Horn et al. 1986) seems an attractive alternative to direct methods which require painstaking quantification of the food consumed. However, the ash-marker method has been criticized (Bjorndal 1985), as absorption of ash has been shown by Buddington (1980). If some of the ash is absorbed, the assimilation efficiency is underestimated. We found the assimilation efficiencies determined by the indirect method to be much lower than those determined by quantification of food consumed and faeces produced. This may well be the result of absorption of some dietary ash. Parrotfish are able to dissolve calcium carbonate in their gut (Smith \& Paulson 1974, 1975). From our own measurements, we know the duodenum, i.e. the first quarter of the gut after the pharyngeal mill, to be slightly acidic ( $\mathrm{pH}=6.5$ to 6.7 ) in both juvenile and adult $S$. viride (pers. obs.). As the ash fraction of epilithic algal turfs consists almost entirely of calcium carbonate, some of this ash fraction probably dissolves during the passage through the gut, resulting in an underestimation of assimilation efficiencies when using the ash-marker method. However, the direct method for estimating the assimilation efficiency also has its drawbacks for JU fish. With the high number of bites taken by JU fish, the daily intake of organic matter can be easily over- or underestimated if a slightly incorrect estimate of the food intake per bite is used.

There was a remarkable difference in assimilation efficiency by fish feeding on a diet that consisted of algae growing on Acropora spp. substrates, collected from the shallow reef zone, compared to those feeding on a diet of algae growing on Montastrea annularis substrates that were collected from the deeper reef zones. Two factors may have contributed to the observed difference in assimilation efficiencies. Firstly, the biomass of epilithic algae on $M$. annularis substrates is higher than on the Acropora spp. substrates, as indicated by a higher total biomass, and a higher percentage cover of epilithic algal turfs. Epilithic algae are more readily accessible for digestion than endolithic and crustose coralline algae. The latter are embedded in a carbonate matrix that has to be ground in the pharyngeal mill to make them accessible for digestion. This notion is supported by the high assimilation efficiency attained by JU fish from their diet of algal turfs, as determined by direct methods (Table 2). Secondly, the higher skeletal density of Acropora spp. substrates will have a negative effect on the pharyngeal grinding efficiency of the carbonate matrix, making the substrate-bound algal fractions less accessible for digestion than those inhabiting lowerdensity substrates like $M$. annularis. For Sparisoma viride, the food scraped off Acropora spp. substrates consists to a large extent of these substrate-bound algal fractions (Fig. 3), resulting in a lower assimilation efficiency.

The assimilation efficiencies for total AFDW, protein and energy determined for Sparisoma viride fall within the range of values reported by Horn (1989) for other herbivorous fish. In adult $S$. viride, assimilation efficiency was highest for protein, intermediate for energy, and lowest for total AFDW. Similar results were obtained by Montgomery \& Gerking (1980), Gerking (1984) and Anderson (1988), using either direct or indirect methods. In JU S. viride, protein assimilation efficiency appeared to be lower than the assimilation efficiency of total AFDW. This result is at odds with other values of the protein assimilation efficiency reported here, or by other authors, and is caused by higher protein levels found in faeces than those measured in their algal food (large turfs). JU $S$. viride probably supplemented their algal diet with the small invertebrates that were inadvertently introduced along with the algae, resulting in a higher protein content of the food than that measured for plant material alone.

\section{Food intake per bite: experimental vs field situation}

The experimentally determined food intake and assimilation efficiency form the basis for estimating the daily intake and assimilation of food, protein and energy by Sparisoma viride foraging on the reef. The size of bites taken by free-living fish was, however, larger than the size of bites taken by fish in experi- 
Table 6. Sparisoma viride. Conversion factor of experimental to field food intake per bite for 2 substrate types

\begin{tabular}{|ccc|}
\hline Fork length $(\mathrm{cm})$ & \multicolumn{2}{c|}{$\begin{array}{c}\text { Conversion factor } \\
\text { Acropora spp. }\end{array}$} \\
\hline 10 & 1.32 & 1.32 \\
20 & 1.44 & 1.41 \\
30 & 1.50 & 1.48 \\
40 & 1.53 & 1.52 \\
\hline
\end{tabular}

mental tanks (Table 4). Therefore, conversion factors were determined. One problem here is that the mean conversion factor for the surface area of bite scars was smaller than the conversion factor for bite-scar volume. We therefore calculated a new conversion factor for total food intake per bite, by weighting the conversion factors of surface area and volume with the relative contribution of epilithic and substrate-bound algal fractions in the bite (Fig. 3). This new conversion factor is dependent on fish size and on substrate type (Table 6).

Another problem in translating the experimentally determined food intake to the field situation lies in the variability of algal biomass in the field. With the leastsquares regression that describes the effect of algal biomass on the food intake per bite (Fig. 2), differences in algal biomass in the field can be corrected for.

Finally, an assumption has to be made concerning the effect of substrate density on the food intake per bite in the field. Grazing on other high-density substrates (for instance Agaricia spp.) is assumed to yield the same amount of food per bite as grazing on the high-density Acropora spp. substrates used in the experiments. Similarly, it is assumed that food intake from other low-density substrates (Madracis mirabilis, Diploria spp. and Colpophyllia natans) is comparable to that attained from low-density Montastrea annularis substrates used in experiments.

\section{Daily intake and assimilation of food, protein and energy in the field}

Total daily bites, food intake, and assimilation of total AFDW, protein and energy $\mathrm{d}^{-1}$ were calculated for 4 size classes feeding on the shallow reef and on the deeper reef respectively (Table 7) using the equations presented in this paper and the diet composition of Sparisoma viride, as described by Bruggemann et al. (1994: Tables 3 \& 4). Daily intake of protein and energy was calculated from the food intake per bite (Fig. 1), the proportion of the food intake derived from epilithic and substrate-bound algal fractions (Fig. 3), and the biochemical composition of these algal fractions (Table 5 in Bruggemann et al. 1994). Daily amounts of food, protein and energy assimilated were calculated using the mean assimilation efficiencies for each diet (Tables $2 \& 3$ ). For juvenile parrotfish, the mean of estimates obtained by the direct and indirect method was used.

In spite of taking more bites, Sparisoma viride feeding on the shallow reef have lower daily food intake, and lower amounts of assimilated AFDW, protein and energy than similarly sized individuals feeding on the deeper reef (Table 7). This is due to a far greater proportion of bites taken by the latter on low-density substrates, dominating the available grazing surfaces on the deeper reef. These substrates yield a higher food intake per bite, and enable a more efficient assimilation of the ingested food. The increased net yield makes territorial defence economically feasible on the deeper reef.

From the mean C contents of the food $(40.5 \%)$, we calculated the daily ingestion of organic $\mathrm{C}$ by Sparisoma viride and some other herbivorous fish. A log-log plot (Fig. 5A) of daily intake of algal $\mathrm{C}$ in relation to fish weight shows that intake by $S$. viride falls in the range of values determined in the field for other tropical herbivorous fish, as reported by Chartok

Table 7. Sparisoma viride. Effects of size and foraging depth on daily food intake and assimilation of algal AFDW, protein and energy

\begin{tabular}{|c|c|c|c|c|c|c|c|}
\hline \multirow{2}{*}{$\begin{array}{l}\text { Foraging depth } \\
\text { Life phase }\end{array}$} & \multirow{2}{*}{$\begin{array}{c}\text { Fork } \\
\text { length } \\
\text { (cm) }\end{array}$} & \multirow{2}{*}{$\begin{array}{c}\text { Fish } \\
\text { wet wt } \\
\text { (g) }\end{array}$} & \multirow{2}{*}{$\begin{array}{c}\text { Total daily } \\
\text { bites }\end{array}$} & \multirow{2}{*}{$\begin{array}{l}\text { Daily food } \\
\text { intake } \\
\text { (g AFDW) }\end{array}$} & \multicolumn{3}{|c|}{ Daily assimilation } \\
\hline & & & & & $\begin{array}{c}\text { Food } \\
\text { (g AFDW) }\end{array}$ & $\begin{array}{l}\text { Protein } \\
\text { (g) }\end{array}$ & $\begin{array}{c}\text { Energy } \\
(\mathrm{kJ})\end{array}$ \\
\hline \multicolumn{8}{|l|}{ Shallow reef } \\
\hline Juveniles & 10 & 17 & 9998 & 0.56 & 0.25 & 0.04 & 7 \\
\hline Initial phase & 20 & 153 & 9763 & 5.35 & 1.25 & 0.32 & 44 \\
\hline Initial phase & 30 & 547 & 7582 & 15.37 & 3.59 & 0.86 & 130 \\
\hline Terminal phase & 40 & 1350 & 4528 & 22.96 & 5.38 & 1.24 & 197 \\
\hline \multicolumn{8}{|l|}{ Deeper reef } \\
\hline Juveniles & 10 & 17 & 8119 & 0.94 & 0.42 & 0.07 & 13 \\
\hline Initial phase & 20 & 153 & 7763 & 7.35 & 4.36 & 0.57 & 104 \\
\hline Initial phase & 30 & 547 & 6041 & 21.36 & 12.71 & 1.57 & 314 \\
\hline Terminal phase & 40 & 1350 & 3551 & 31.73 & 18.91 & 2.28 & 474 \\
\hline
\end{tabular}



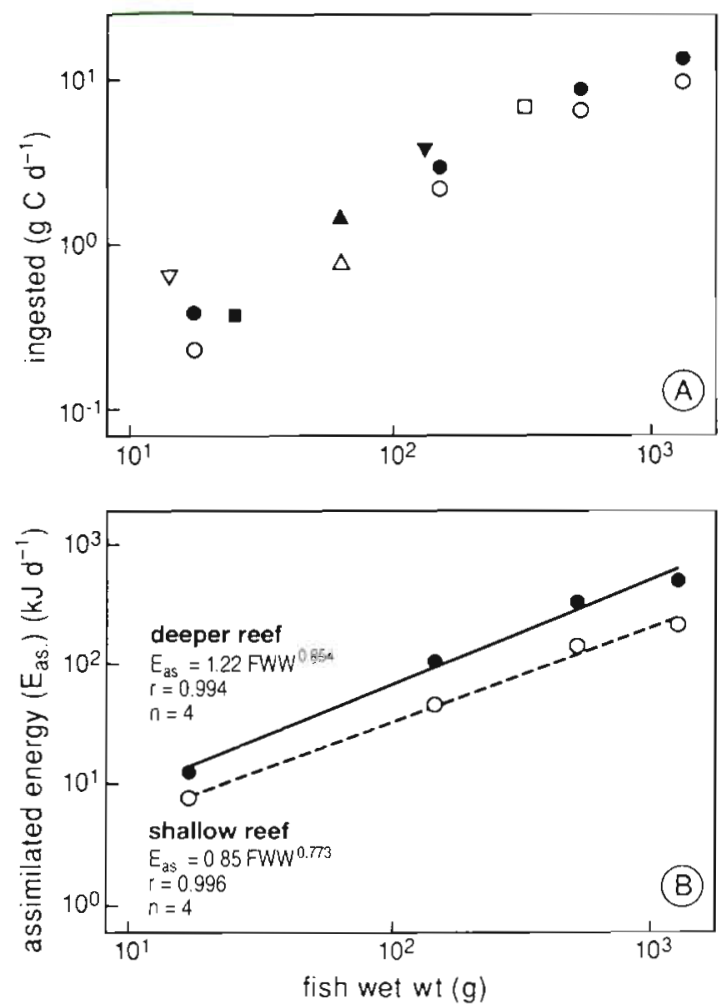

Fig. 5. (A) Daily intake of algal carbon by herbivorous fish versus fish wet wt (FWW). Circles represent values for Sparisoma viride foraging on (0) the shallow reef and (0) the deeper reef. Other values were recalculated from Chartok (1983) for Acanthurus guttatus ( $\square$ ), Gerking (1984) for Sarpa salpa (maintenance ration: 口), Polunin (1988) for Plectroglyphidodon lacrymatus (winter: $\Delta_{i}$ summer: $\Delta$ ), Klumpp \& Polunin (1989) for Stegastes apicalis $(\nabla)$, and Montgomery et al. (1989) for Acanthurus nigrofuscus ( $\mathbf{\nabla}$ ). (B) Daily assirnilated energy $\left(E_{\text {as. }}\right)$ by various size $S$. viride foraging on the deeper reef and the shallow reef, respectively

(1983), Polunin (1988), Klumpp \& Polunin (1989) and Montgomery et al. (1989), and the experimentally determined maintenance ration for the temperate herbivorous fish Sarpa salpa (Gerking 1984).

In Fig. 5B the relation of daily assimilated energy to fish weight is shown for Sparisoma viride foraging on the deeper reef and the shallow reef, respectively. The weight exponents of the functions fitted through the data points are close to 0.8 , and are within the range of values reported for daily food intake by fish as determined in experimental studies (Elliott 1975, Pálsson et al. 1992; see Jobling 1993 for review). Weight exponents $<1$ for daily assimilated energy indicate lower mass-specific energy requirements in larger fish. With increasing size, an increasing proportion of the food is derived from substrate-bound algal fractions. Exploiting these food resources probably involves additional costs of excavating and grinding these limestoneembedded algae. In this study we quantified the effects of social organization, life phase and size on the daily amounts of ingested and assimilated algal nutrients and energy. It provides a necessary step for further evaluation of the daily balance of energy intake and allocation by this large herbivorous reef fish. Secondly, it provides a basis for quantifying the impact of scarid grazing on the algal food supply, and for an assessment of their contribution to the energy flow in coral reef ecosystems.

Acknowledgements. We thank the Bonaire Marine Park authorities for permission to carry out the work on the unspoiled reefs of Bonaire, and for working facilities at Karpata Ecological Centre. We also thank Director Roberto Hensen for offering working facilities at Marcultura, Bonaire. We are indebted to Onno Diekman and Madeleine van Oppen for their enthusiastic participation in experiments and underwater observations, and to Jules van Rooij, Theunis Piersma and 2 anonymous reviewers for helpful comments on the manuscript. Special thanks are due to Anne van Kessel who spent many days patiently observing, collecting and measuring scarid bite scars. J.H.B. was supported by a grant from the Netherlands Foundation for the Advancement of Tropical Research (WOTRO) W84-280; their support is gratefully acknowledged. This is a project in the context of the program 'Resilience of Coral Reefs', a cooperative effort of the Dept of Marine Biology, University of Groningen (A.M.B. \& J. J. Videler), the Netherlands Institute for Sea Research (R. P. M. Bak), and the Institute of Taxonomic Zoology (R. W. M. van Soest).

\section{LITERATURE CITED}

Anderson, T A. (1988). The effect of feeding frequency on utilization of algal nutrients by the marine herbivore, the luderick, Girella tricuspidata (Quoy and Gaimard). J. Fish. Biol. 32: 911-921

Bellwood, D. R., Choat, H. (1990). A functional analysis of grazing in parrotfish (family Scaridae) the ecological implications. Environ. Biol. Fish. 28: 189-214

Bjørndal, K. A. (1985). Use of ash as an indigestible dietary marker. Bull. mar. Sci. 36: 224-230

Bowen, S. H. (1987). Dietary protein requirements of fish - a reassessment. Can. J. Fish. Aquat. Sci. 44: 1995-2001

Brock, R. E. (1979). An experimental study of the effects of grazing by parrotfish and role of refuges in benthic community structure. Mar. Biol. 51: 381-388

Bruggemann, J. H., van Oppen, M. J. H., Breeman, A. M. (1994). Foraging by the stoplight parrotfish Sparisoma vinide. I. Food selection in different, socially determined habitats. Mar. Ecol. Prog. Ser. 106: 41-55

Buddington, R. K. (1980). Hydrolysis-resistant organic matter as a reference for measurement of fish digestive efficiency. Trans. Am. Fish. Soc. 106: 653-656

Carpenter, R. C. (1986). Partitioning herbivory and its effects on coral reef algal communities. Ecol. Monogr. 56: 345-363

Chartok, M. A. (1983). The role of Acanthurus guttatus (Bloch and Schneider 1801) in cycling algal production to detritus. Biotropica 15: 117-121

Choat, J. H. (1991). The biology of herbivorous fish on coral reefs. In: Sale, P. F. (ed.) Ecology of fish on coral reefs. Academic Press, London 
Choat, J. H., Bellwood, D. R. (1985). Interactions amongst herbivorous fish on a coral reef: influence of spatial variation. Mar. Biol. 89: 221-234

Craigie, J. S. (1974). Storage products. In: Steward, W. D. P. (ed.) Algal physiology and biochemistry. Blackwell Scientific Publications, London

Dring, M. J. (1984). Photoperiodism and phycology. In: Round, F. E., Chapman, D. J. (eds.) Progress in phycological research, Vol. 3. Elsevier Biomedical Press, Amsterdam

Elliott, J. M. (1975). Number of meals in a day, maximum weight of food consumed in a day and maximum rate of feeding for brown trout, Salmo trutta L. Freshwat. Biol. 5: $287-303$

Fish, G. R. (1960). The comparative activity of some digestive enzymes in the alimentary canal of tilapia and perch. Hydrobiologia 15: 161-178

Gerking, S. D. (1984). Assimilation and maintenance ration of an herbivorous fish, Sarpa salpa, feeding on green alga. Trans. Am. Fish. Soc. 113: 378-387

Gladstone, W. (1988). Correlates and possible costs of reproductive success in males of a haremic coral reef fish. Proc. 6th int. coral Reef Symp. 2: 693-698

Gnaiger, E., Bitterlich, G. (1984). Proximate biochemical composition and caloric content calculated from elemental CHN analysis: a stoichiometric concept. Oecologia 62: $289-298$

Gohar, H. A. F., Latif, A. F. A. (1961). The carbohydrases of some scarid and labrid fish (from the Red Sea). Publ. mar. biol. Stn Ghardaga 11: 127-146

Gygi, R. A. (1975). Sparisoma viride (Bonnaterre), the stoplight parrotfish, a major sediment producer on coral reefs of Bermuda? Eclog. geol. Helv. 68: 327-359

Hanley, F. (1984). Time-budgeting and foraging strategy of the stoplight parrotfish Sparisoma viride Bonnaterre, in Jamaica. J. exp. mar. Biol. Ecol. 83: 159-177

Hashimoto, S., Shogren, M. D., Pomeranz, Y. (1987). Serial pentosanes: their estimation and significance. I. Pentosanes in weed and milled weed products. Ser. Chem. 64: 30-34

Hatcher, B. G. (1983). Grazing in coral reef ecosystems. In: Bames, D. J. (ed.) Perspectives on coral reefs. Australian Institute of Marine Science, Townsville

Hatcher, B. G., Larkum, A. W. D. (1983). An experimental analysis of factors controlling the standing crop of the epilithic algal community on a coral reef. J. exp. mar. Biol. Ecol. 69: 61-84

Horn, M. H. (1989). Biology of marine herbivorous fish. Oceanogr. Mar. Biol. A. Rev. 27: 167-272

Horn, M. H., Neighbors, M. A. (1984). Protein and nitrogen assimilation as a factor in predicting the seasonal macroalgal diet of the monkeyface prickleback. Trans. Am. Fish. Soc. 113: 388-396

Horn, M. H. Neighbors, M. A., Murray, S. N. (1986). Herbivore responses to a seasonally fluctuating food supply: growth of two temperate intertidal fish based on the protein and energy assimilated from their macroalgal diets. J. exp. mar. Biol. Ecol. 103: 217-234

Jobling, M. (1993). Bioenergetics: feed intake and energy partitioning. In: Rankin, J. C., Jensen, F. B. (eds.) Fish ecophysiology. Chapman \& Hall, London

Klumpp, D. W., Polunin, N. V. C. (1989). Partitioning among grazers of food resources within damselfish territories on a coral reef. J. exp. mar. Biol. Ecol. 125: 145-169

Lewis, S. M. (1986). The role of herbivorous fish in the organization of a Caribbean reef community. Ecol. Monogr 56: $183-200$

Montgomery, W. L., Gerking, S. D. (1980). Marine macroalgae as food for fish: an evaluation of potential food quality. Environ. Biol. Fish. 5: 143-153

Montgomery, W. L., Myrberg, A. A., Fishelson, L. (1989). Feeding ecology of surgeonfish (Acanthuridae) in the norther Red Sea, with particular reference to Acanthurus nigrofuscus (Forsskål). J. exp. mar. Biol. Ecol. 132: 179-207

Morse, E. E. (1949). Anthrone in estimating low concentrations of sucrose. Analyt. Chem. 19: 1012-1013

Norusis, M. J. (1990). SPSS/PC+ 4.0 for the IBM PC/XT/AT and PS/2. Vol. I, Base manual; Vol. II, Statistics; Vol. III, Advanced statistics. SPSS Inc., Chicago

Pálsson, J. Ö., Jobling, M., Jorgensen, E. H. (1992). Temperal changes in daily food intake of Arctic charr, Salvelinus alpinus L. of different sizes monitored by radiography. Aquaculture 106: 51-61

Polunin, N. V.C., (1988). Efficient uptake of algal production by a single resident herbivorous fish on the reef. J. exp. mar Biol. Ecol. 123: 61-76

Polunin, N. V. C., Klumpp, D. W. (1989). Ecological correlates of foraging periodicity in herbivorous reef fish of the coral sea. J. exp. mar. Biol. Ecol. 126: 1-20

Russ, G. R. (1984a). Distribution and abundance of herbivorous grazing fish in the Central Great Barrier Reef. I. Levels of variability across the entire continental shelf. Mar. Ecol. Prog. Ser. 20: 23-34

Russ, G. R. (1984b). Distribution and abundance of herbivorous grazing fish in the Central Great Barrier Reef. II. Patterns of zonation of mid-shelf and outershelf reefs. Mar. Ecol. Prog. Ser. 20: 35-44

Russ, G. R. (1987). Is rate of removal of algae by grazers reduced inside territories of tropical damselfish? J. exp. mar. Biol. Ecol. 110: 1-17

Russ, G. R., St. John, J. (1988). Diets, growth rates and secondary production of herbivorous coral reef fish. Proc. 6th int. coral Reef Symp. 2: 37-43

Smith, R. L., Paulson, A. C. (1974). Food transit times and gut pH in two Pacific parrotfish. Copeia 3: 796-799

Smith, R. L., Paulson, A. C. (1975). Carbonic anhydrase in some coral reef fish: adaptation to carbonic ingestion? Comp. Biochem. Physiol. 50A: 131-134

Steneck, R. S. (1988). Herbivory on coral reefs: a synthesis. Proc. 6th int coral Reef Symp. 1: $37-49$

Williams, D. McB. (1982). Patterns in the distribution of fish communities across the central Great Barrier Reef. Coral Reefs $1: 35-43$

Zoufal, R., Taborsky, M. (1991). Fish foraging periodicity correlates with daily changes of diet quality. Mar. Biol. 108: $193-196$

Manuscript first received: June 24, 1993

Revised version accepted: December 22, 1993 